\title{
ANALYSIS OF THE RELATIONSHIP BETWEEN INFLATION AND CENTRAL BANK INTEREST RATES IN TURKEY: FOURIER APPROACH
}

\author{
Esra N. KILCl ${ }^{1}$
}

\begin{abstract}
Within the framework of inflation targeting program officially implemented since 2006, the primary objective of the Central Bank of Republic of Turkey is to achieve and maintain price stability. As a result of instrumental independence, the CBRT determines, at its own discretion, the monetary policy it would implement and the policy instruments it would use in achieving and maintaining price stability. In this context, The CBRT uses a policy mix including one-week repo rate, the interest rate corridor between $\mathrm{O} / \mathrm{N}$ borrowing and lending rates as well as reserve requirements to achieve price stability and to provide financial stability with regard to controlling of financial risks which have the potential to threat price stability. The aim of this study is to investigate the longterm relationship between the $\mathrm{O} / \mathrm{N}$ repo rates to approximate central bank interest rates and the consumer price index to approximate inflation during the period of 2005-2017. Using monthly data, the Fourier Granger Causality Test is employed to test the relationship between $\mathrm{O} / \mathrm{N}$ repo rates and $\mathrm{CPI}$. The findings indicate that there is a oneway causality relationship from $\mathrm{O} / \mathrm{N}$ repo rates to $\mathrm{CPI}$.
\end{abstract}

Keywords: Price Stability, CBRT, Interest Rates, Inflation

Jel Classification: E40, E43, E58.

\section{TÜRKIYE'DE ENFLASYON VE MERKEZ BANKASI FAIZ ORANLARI ARASINDAKI ILIŞKININ ANALIZI: FOURIER YAKLAŞIMI}

Öz

2006 yılından itibaren uygulanan enflasyon hedeflemesi programı doğrultusunda, Türkiye Cumhuriyeti Merkez Bankası'nın temel amacı, fiyat istikrarını sağlamak ve sürdürmektir. Merkez Bankası'nın bağımsızlığı prensibinin bir sonucu olarak, TCMB, nihai hedefi olan fiyat istikrarını sağlamak için uygulayacağı para politikasını ve politika araçlarını serbestçe belirlemektedir. Bu çerçevede, TCMB fiyat istikrarını sağlamak ve aynı zamanda fiyat istikrarını tehdit etme potansiyeline sahip finansal riskleri kontrol etmeye yönelik olarak finansal istikrarı sürdürmek için haftalık repo oranını, gecelik borçlanma ve borç verme oranları arasındaki faiz oranı koridorunu ve karşılık oranlarını kullanmaktadır. Bu çalışmanın amacı, 2005-2017 döneminde, merkez bankası faiz oranları (gecelik repo oranları) ve enflasyon (TÜFE) oranı arasındaki nedensellik ilişkisini Fourier Granger Causality Test yardımıyla araştırmaktır. Çalışma sonuçları, gecelik repo oranları ve TÜFE oranı arasında tek yönlü bir nedensellik ilişkisi olduğuna işaret etmektedir.

Anahtar Kelimeler; Fiyat istikrarı, TCMB, Faiz Oranları, Enflasyon

Jel Kodları: E40, E43, E58.

1 Asst. Prof. Dr., Istanbul Arel University, International Trade\&Finance Department, ORCID: 0000-0002-2239-4560, esrakilci@arel.edu.tr 


\section{Introduction}

Price stability is generally defined a low and stable rate of inflation maintained over a prolong period of time (Poole and Weelock, 2008: 6). In principle, inflation can be defined as a continuous increase in the general prices of goods and services over an extended period, resulting in a sustained decline in the value of money and thereby its purchasing power. Inflation is a significantly important economic phenomenon meaning price instability that could have highly negative consequences for the economies such as distorting vital relative-price signals (Humpage, 2008: 2), eroding the purchasing power of savings, discouraging investments, directing capital flows from productive investments to non-productive investments such as real-estate and gold, giving damage to growth and leading to failure in economic planning (Debelle et al, 1998: 1). As some groups in society who earn fixed or low income have restricted capabilities to hedge against inflation, it also has a disproportionate effect in terms of wealth distribution.

Of objectives of monetary policy implemented by central banks, the goal of price stability is the primary objective and has great value. According to central bankers and economists' view, the variability of employment and output is balanced by price stability in the short to medium term and contributes significantly to the economy's growth and employment expectations in the long term (Bernanke, 2006). In fact, price stability is not only a goal but also an intermediate target of monetary policy.

Before analyzing the impacts of price stability, it would be beneficial to define what central bankers generally mean by the term. For most central banks, term of "price" is defined as the aggregate measure of the prices of currently produced goods and services. This could be either the CPI or some NIA deflator, with or without some sectoral exemptions to clean the series of undesired volatility. Over the longer term, these series have a tendency to move quite closely together so that the distinctions between them become less determining. Nonetheless, definitional differences can become important over shorter time periods such as a few year horizons. For instance, the upward trend in energy prices can drive a wedge between measures which include such prices and those that do not. The traditional approach would be to define "stable" as some low level of inflation, between one half of one percent and $\% 2$ to $\% 3$ annually (White, 2006: 2).

To be able to achieve and maintain price stability has a series of benefits. Firstly, it becomes easier to recognize relative price changes for consumers and companies. Price stability supports economic growth and better living standards by reducing uncertainty concerning general price movements and enhancing the transparency of the price mechanism. Stable prices enable much more efficient allocation of resources by allowing economic agents to make better decisions about what they produce and how they produce. Price stability avoids people diverting scarce resources to hedging against inflation. It improves general well-being by reducing inflation risk premium in interest rates, by rendering activities which focus on hedging against inflation risk and by reducing the negative effects of social security and taxation systems. High and variable inflation lead to increase in demand for highrisk premium and discourages both long-term savings and investments. Since continuous unstable prices cause lenders to demand a higher interest rate to compensate for the risk and lead to increases in the cost of finance, as a result of upward trend in the long-term interest rates, long-term projects become prohibitively costly. Achieving and maintaining price stability has great effect for several economic and social objectives to be achieved. The disproportionate distribution of wealth and income can be avoided with the help of maintaining price stability. Since high inflation leads to an erosion of the real value of nominal assets like savings in the form of bank deposits, T- Bills and government bonds as well as nominal wages, social distress and political instability increases. By achieving and maintaining 
price stability, central banks focus on other macro-economic targets such as sustainable growth in investment, output and employment to contribute to provide financial stability (ECB, 2009: 7)

Inflation targeting is an efficient monetary policy mostly implemented by the countries which suffered high and unstable inflation rates for a long period and then aimed to provide price stability by setting a specific inflation target as a goal. Countries implementing inflation targeting program and announcing a specific quantitative target for inflation highly reduces uncertainty relating to the longterm inflation rate, especially when supported with institutional reforms. If the program is strengthened by providing instrumental independence, it leads to decrease in both inflation risk premium as well as interest rates and encourages long-term investments. The countries that have had a history of high or unstable inflation benefited from inflation targeting programs considerably and managed to decrease inflation rates to more moderate levels (Poole and Weelock, 2008: 7).

In Turkey, struggling with very high inflation rates especially pre-2000 period, an implicit inflation targeting program was applied at first and after confirming that favorable terms were appeared, the Central Bank of Republic of Turkey launched to implement inflation targeting program since 2006. Although a significant improvement in the inflation rate was observed, that is, inflation rates at around $\% 70$ in 2001, continued to stay in single digit values except the years of 2008 and 2011, it has taken a double-digit value above $\% 10$ in the year of 2017. As a result of the factors which leads to upward movement in inflation rate and that could be summarized as the depreciation of the Turkish Lira against the currency basket, rising import prices and significant increases in energy and food prices, consumer inflation which is measured by CPI ended 2017 at \%11,92 (CBRT, 2018a: 1). Inflation having an alarming trend recently brought about the concerns relating to inflation targets and the credibility of the CBRT.

In the framework of inflation targeting regime implemented since 2006, the primary objective of the CBRT is to achieve and maintain price stability. The Bank determines its own monetary policy to pursue and the policy instruments to use in achieving and maintaining price stability. As a result, the CBRT has instrumental independence, as the other central banks of many developed economies. To achieve price stability and to control risks relating to financial stability, the Central Bank uses a monetary policy combination including one-week repo rate, the interest rate corridor between $\mathrm{O} / \mathrm{N}$ borrowing and lending rates, and reserve requirements (CBRT; 2016). Moreover, The CBRT implements open market operations serving only to monetary policy purposes in order to make that the short-term interest rates realize around the one-week repo rate which is declared as policy rate and to regulate liquidity in the financial markets.

Open Market Operations are basically the central bank's purchase and sale of securities in financial markets. Under open market operations, the central bank influences money supply, the level of bank reserves and interest rates by adjusting policy interest rates and trading T-bills and central bank securities. The process related to changes in monetary policy affecting the general price level and output in the economy through their impact on aggregate demand is referred to monetary policy transmission mechanism. Although the main objective of open market operations has been to control short-term interest rates and the money supply, this tool has effectively been used to affect long-term interest rates and to support the flow of credit in the financial system after the recent financial crisis (Barcin, 2012: 29).

Under the present system of Open Market Operations, the CBRT which ensures short-term interest rates to occur at pre-defined levels and regulates the liquidity in financial markets has instruments such as repo- reverse repo auctions, outright purchases and sale transactions, deposit facilities and liquidity bills. Repo transactions are generally used to temporarily increase or decrease the liquidity of the banking system in case which there is temporary funding need or excess liquidity. CBRT injects liquidity into the market when unexpected liquidity shortage puts pressure on money market interest rates and

\section{Uluslararası İktisadi ve İdari İncelemeler Dergisi}


withdraws liquidity from the market when there is liquidity excess through repo auctions. CBRT adjust liquidity in the financial markets by bidding at CBRT O/N borrowing interest rate (CBRT; 2018b).

Although one-week repo rate is declared as policy rate in monetary policy conducted by CBRT, O/N repo rates have great impact on daily funding of banking sector and in determining market interest rates in practice. The purpose of this study is to test the causality relationship between $\mathrm{O} / \mathrm{N}$ repo rates and CPI over the period of 2005-2017. The Fourier KPSS Unit-root Test and Fourier Granger Causality Test are employed by using the related data provided through CBRT.

\section{Literature Review}

The relationship between interest rates and inflation has been one of the commonly analyzed subjects by many researchers both theoretically and empirically. Both the impact of interest rates on inflation and the effect of inflation on interest rates have been investigated in these studies.

Pennachi (1991) examined the relationship between real interest rates and inflation. After employing a model including observations on Treasury bills with different maturities and NBER-ASA survey forecasts of inflation for the period of 1968-1988, Pennachi found that real interest rates and expected inflation were significantly negatively correlated. Mishkin (1992) tested the evidence of Fisher effect ${ }^{1}$ for U.S economy by using the data on inflation rate and one to twelve-month U.S T-Bill rate during the period of 1964-1986 and found that there was a long-run Fisher effect implying that when inflation and interest rates exhibited trends, these two series would trend together, so there would be a strong correlation between inflation and interest rates. Mishkin and Simon (1995) also examined the positive relationship between the expected inflation rate and the interest rate in Australia by using co-integration test and quarterly data in the period of 1962-1993. Their results indicated that although Fisher effect was valid in the long-run, there is no evidence of a short-run Fisher effect.

Crowder and Hoffman (1996) investigated the long-run relationship between the short-term nominal interest rates and inflation by using quarterly data through co-integration analysis. They found that the three-month U.S T-bill rate and the expected inflation were co-integrated sharing a common stochastic trend. Their findings seemed consistent with the implications of the Fisher equation and they also found that the inflation rate introduced information about the future path of the nominal interest rates. Paleologos and Georgantelis (1999) investigated the Fisher effect in Greece by using cointegration test and quarterly data on 3-month T-Bill rate and inflation rate during the period of 19801996. They found that Fisher effect was valid in the long-term. Booth and Ciner (2001) studied the relationship between interest rate and inflation rate using co-integration in 9 European countries and the U.S.A. The results supported the long-run relationship except for one case.

Berument and Mehdi (2002) tested Fisher effect in a sample of 26 developed and developing countries using monthly data on T-Bill rates and inflation rates. They found that Fisher hypothesis holds more for the developed countries than the developing countries. Million (2003) tested the long-run relationship between nominal interest rates and inflation rates using U.S. data and found evidence in favor of Fisher theory. Million concluded that Federal Reserve reduced the nominal interest rate when inflation rate was high; and FED raised nominal interest rate when inflation rate was low and also argued that FED authorities followed prices fixing policy and regulated its procedures based on

\footnotetext{
${ }^{1}$ According to the Fisher hypothesis, there is a positive relation between nominal interest rate and inflation. Fama (1975), using one-month T-Bill interest rates and CPI in his study, argued that nominal interest rates reflected future price changes. The results showed that, U.S T-Bill market was efficient and the real return on T-Bill of various maturities was compatible with rational expectations theory.
} 
inflation. Lardic and Mignon (2003) investigated the relationship between interest rate and inflation rate in G-7 countries by using Engle-Granger Test and found a long-run relationship between interest rate and inflation rate.

Gul and Ekinci (2006) analyzed the relationship between nominal interest rates and inflation for Turkey during the period of 1984-2003. They found both a long-run relationship between interest rates and inflation by using co-integration test and a causality existed in one direction from nominal interest rates to inflation by employing Granger Causality Test. Herwartz and Reimers (2006) examined the implications of the Fisher hypothesis and investigated the relationship between inflation and interest rates for more than 100 economies in a 45-year period using monthly time series data. Their results from panel unit root and co-integration tests indicated that interest rates and inflation were cointegrated.

Argyro (2010) examined the Fisher effect in OECD countries using the quarterly data on short-term interest rates and inflation rates. According to the results, full Fisher effect was valid for Canada and partial Fisher effect was present for Belgium and Korea. Ray (2012) tested the international Fisher effect in U.S.A and some Asian countries using the quarterly data on interest rates and inflation rates in the period of 2001-2012 and found that partial Fisher effect was present in U.S.A. Incekara et al (2012) tested the Fisher effect in Turkey by using the seasonal series during the period of 1989-2011. To investigate the validity of Fisher Hypothesis for Turkish economy, they employed Johansen Cointegration and Granger Causality Tests. According to their results, Fisher impact was valid for Turkish economy in the long-term.

Guris et al (2016) investigated the validity of the Fisher Hypothesis in Turkey in the period of 20032012. To test validity of Fisher Hypothesis, they used an Autoregressive Distributed Lag Test for threshold co-integration introduced in the literature by Li and Lee (2010). The empirical results indicated that Fisher hypothesis was valid for Turkey. Ioana (2017) examined the impact of low interest rates adopted by Central and Eastern Europe countries which implemented inflation targeting programs and investigated the existence of Neo-Fisher effect which could demonstrate the positive relation between interest rates and inflation. The findings indicated that there was a significant positive relation between the variables and negative shocks to interest rates resulted in lower inflation.

\section{Econometric Analysis}

\subsection{Data and Methodology}

In this study, the relationship between central bank interest rates and inflation is being analyzed using Fourier Approach. The period ranges from 2005 to 2017 and covers the year of 2006 which is a crucial point. Because after executing an implicit inflation targeting program in the period of 20022005 , the CBRT launched to implement inflation targeting program officially in 2006. According to that program, the primary objective of the CBRT is to achieve and maintain price stability. Since the beginning of the 2003, inflation has declined sharply and is now above $\% 15$ according to the data taken from CBRT. In investigation of the relationship between variables, $\mathrm{O} / \mathrm{N}$ repo rates to approximate central bank interest rates and CPI to approximate inflation, obtained from CBRT, have been used. In the first stage, Fourier KPSS Stationary Test has been employed to test the stationary of the variables. The Fourier test developed by Becker et al (2006) can detect not only sudden changes but also slow changes and the position, number and form of structural changes do not affect the power of the test. Subsequently, Fourier Granger Causality Test has been employed to test the causality relationship between variables. The VAR with Fourier Frequencies which has been employed by Enders and Jones (2015) that uses Flexible Fourier Form yields powerful results. After introducing trigonometric functions into the model, they found a richer set of interactions between the variables.

\section{Uluslararası İktisadi ve İdari İncelemeler Dergisi}


Table 1: Variables and Expected Relationship

\begin{tabular}{lllc}
\hline & Variables & Measure & Expected Relationship \\
\hline Dependent Variable & Inflation & Consumer Price Index (CPI) & $(+)$ \\
Independent Variable & Central Bank Int. Rate & O/N Repo Rates & \\
\hline
\end{tabular}

\subsection{Analysis and Results}

Since there is generally no specific information relating to the definite nature of the breaks and no practical knowledge about the location and the number of breaks to use in testing for stationary, using an incorrect specification for the number or form of breaks might create some dilemma such as ignoring the breaks together. Becker et al (2006) developed a stationary test in which a chosen frequency component of a Fourier function was used to estimate the deterministic components of the model. A Fourier series could effectively model the behavior of an unknown function even though this function is not regular. In this stationary test, that the Fourier function capturing the movements of the unknown function is the primary reason for applying it. The Fourier test developed by Becker et al (2006) can detect not only sudden changes but also slow changes and the position, number and form of structural changes do not affect the power of the test. For this reason, the performance of the tests was substantially robust to several kinds of structural breaks often seen in economic analysis, including the breaks of opposite signs (Tsong; 2016).

The methodology developed by Becker et al (2006) seems strong to notice sharp and u-shaped breaks as well as smooth breaks near the end of a series and it functions best when breaks are gradual. Becker et al (2006) employ trigonometric terms to capture unknown nonlinearities. The test they developed is a KPSS-type stationary test (Becker et al; 2006).

Becker at al (2006) take into account the following DGP;

$$
\begin{aligned}
& y_{t}=X t^{\prime} \beta+Z t^{\prime} \gamma+r_{t}+\varepsilon_{t} \\
& r_{t}=r_{t-1}+u_{t},
\end{aligned}
$$

where $\varepsilon_{t}$ are stationary errors and $u_{t}$ are independent and identically distributed with variance $\sigma_{u}{ }^{2}$. It is chosen $Z_{t}=[\sin (2 \pi k t / T), \cos (2 \pi k t / T)]^{\prime}$ to capture a break in the deterministic term, where $\mathrm{k}$ represents the frequency and $\mathrm{T}$ is the sample size. Here, to test whether $y_{t}$ is stationary or not, it is defined as $X_{t}=[1]$ for a level-stationary process for $y_{t}$ and $X_{t}=[1, t]^{\prime}$ for a trend-stationary process.

At the start, one of the models described below is estimated and the residuals are obtained, in order to acquire the $\mathrm{t}$-statistic required for testing the null hypothesis $\left(\mathrm{H}_{0}=\sigma_{u}{ }^{2}=0\right)$;

$$
\begin{aligned}
& y_{t}=\propto_{0}+\gamma_{1} \sin \left(\frac{2 \pi k t}{T}\right)+\gamma_{2} \cos \left(\frac{2 \pi k t}{T}\right)+e_{t} \\
& y_{t}=\propto_{0}+\beta t+\gamma_{1} \sin \left(\frac{2 \pi k t}{T}\right)+\gamma_{2} \cos \left(\frac{2 \pi k t}{T}\right)+e_{t}
\end{aligned}
$$

The following test statistics is obtained;

$$
\tau_{\mu}(k) \operatorname{or} \tau_{\tau}(k)=\frac{1}{T^{2}} \frac{\sum_{t=1}^{T} \tilde{S}_{t}(k)^{2}}{\widetilde{\sigma}^{2}}
$$


where $\tilde{S}_{t}(k)=\sum_{j=1}^{t} \tilde{e}_{j}$ and $\tilde{e}_{j}$ are the OLS residuals from the regression (2) for $\tau_{\mu}(k)$ or (3) for $\tau_{\tau}(k)$. As in KPSS, a nonparametric estimate $\tilde{\sigma}^{2}$ of the long-run variance could be obtained by choosing a truncation lag parameter $I$ and a set of weights $w_{j, j},=1, \ldots, l$;

$$
\tilde{\sigma}^{2}=\tilde{\gamma}_{0}+2 \sum w_{j} \tilde{\gamma}_{j},
$$

where $\tilde{\gamma}_{j}$ is the jth sample auto-covariance of the residuals $\tilde{e}_{t}$ from eqn (2) or (3).

To determine the optimal number of $k$, the value which gives the minimum sum of residuals (OLS) would be selected. In case the non-linear trend is not present in DGP, the standard KPSS test could be applied to obtain increased power. As it seems useful to test for the absence of a non-linear trend, Becker et al (2006) proposed that F-test statistic to be used. Therefore, the following F-test statistic for this hypothesis (absence of a nonlinear trend (i.e. $\gamma_{1}=\gamma_{2}=0$ ) could be calculated against the alternative of a nonlinear trend with a given frequency $k$.

$$
F_{i}(k)=\frac{\left(S S R_{0}-S S R_{1}(k)\right) / 2}{S S R_{1}(k) /(T-q)} \quad \mathrm{i}=\mu, \mathrm{\tau},
$$

The F-test could be used only if the null of stationary is rejected. The standard KPSS test statistic would be used in case trigonometric terms are not significant. In comparison with the critical values related to Fourier Test which are shown in the study of Becker et al (2006), the results of the stationary test are stated below;

\begin{tabular}{|c|c|c|c|c|}
\hline Variable & Frequency & MinSSR & FKPSS & F-Statistic \\
\hline $\mathrm{CPI}$ & 1 & 421,868 & $0,074411^{* * *}$ & 11,63726 \\
\hline O/N Repo Rate & 1 & 1046,54 & $0,262712^{*}$ & 197,7657 \\
\hline \multicolumn{3}{|c|}{ FKPSS Critical Values } & \multicolumn{2}{|c|}{ F-Statistic Critical Values } \\
\hline $1 \%$ & 0,2709 & & & 6,281 \\
\hline $5 \%$ & 0,1696 & & & 4,651 \\
\hline $10 \%$ & 0,1294 & & & 3,935 \\
\hline
\end{tabular}

Table 2: Stationary Test Results

As seen in the Table 2, the CPI and O/N Repo Rate variables are stationary. According to the F-Test results which are used to test the significancy of the trigonometric terms, it seems that trigonometric terms for both variables are significant when the values are compared with the F-Statistic Critical Values which are shown in the study of Becker et al (2006).

In the second stage, it is employed Fourier Granger Causality Test proposed by Enders and Jones (2015) in this study in order to investigate the causal linkages between O/N repo rates and inflation rates. Since the linkages between the variables have been subjected to gradual shifts and linear specifications are mostly inappropriate to capture the relationships, econometric examinations are not generally direct and simple. Enders and Jones (2015) allows the Flexible Fourier form to capture the multiple smooth mean shifts that are likely to be present in the VAR system. In one respect, their results complement those of Enders and Holt (2014) who estimate a VAR with LSTAR mean shifts. While they focus on long-run mean shifts, Enders and Jones focus on Granger Causality Tests and on the short-run dynamics of the system. 
Instead of estimating the number, form, and the size of the breaks, Enders and Jones tried the Flexible Fourier Form to control for breaks in a VAR and after they tested the non-stationary of variables, they considered the linear VAR as following;

$$
z_{t}=\delta+\sum_{i=1}^{11} A_{i} z_{t-i}+e_{t}
$$

where $\delta$ is a $(4 \times 1)$ vector of intercepts, $A_{i}$ is a $(4 \times 4)$ coefficient vector and $e_{t}$ is the vector of innovations. Although the responses seem reasonable, they have some problems for two reasons. First, to the extent that there are neglected structural breaks, the system given by (7) is misspecified. Second, given that an unrestricted VAR is likely to be over parameterized, the confidence intervals shown in the figure may be unnecessarily large. In order to show how neglected breaks can interfere with Granger Causality Tests, they followed a standard recommendation and limited the VAR by imposing the restrictions implied by the Granger Causality Tests. Their results indicated that there is very little interaction among the variables. The significant responses are such that series tend to respond only to their own shocks.

Then, Enders and Jones allowed the deterministic regressors be as following, instead of the VAR given by (7);

$$
\begin{aligned}
& z_{t}=\delta(t)+\sum_{i=1}^{11} A_{i} z_{t-i}+e_{t} \\
& \delta(t)=\left[\delta_{1}(t), \delta_{2}(t), \delta_{3}(t), \delta_{4}(t)\right]^{\prime}
\end{aligned}
$$

and each intercept $\delta_{i t}$ depends on $\mathrm{n}$ Fourier frequencies such that;

$$
\delta_{i}(t)=a_{i}+b_{i} t+\sum_{k=1}^{n} a_{i k} \sin \left(\frac{2 \pi k t}{T}\right)+b_{i k} \cos \left(\frac{2 \pi k t}{T}\right)
$$

When the Fourier terms are used to control for breaks, the Granger Causality results change from those documented before in several important ways. In contrast to the Granger Causality results indicated by the linear VAR, when Enders and Jones (2015) put trigonometric functions into the model, they detected stronger relations and richer sets of interactions between the variables.

Table 3: Causality Test Results

\begin{tabular}{lllcccc}
\hline Relationship & $\begin{array}{l}\text { Single/Cumulative } \\
\text { Frequency }\end{array}$ & $\begin{array}{c}\text { Optimal } \\
\text { Frequency }\end{array}$ & Wald-stat & $\begin{array}{c}\text { Asymptotic } \\
\text { p-value }\end{array}$ & $\begin{array}{c}\text { Bootstrap } \\
\text { p-value }\end{array}$ & $\begin{array}{c}\text { Optimal } \\
\text { Lag }\end{array}$ \\
\hline $\mathrm{O} / \mathrm{N} \rightarrow \mathrm{CPI}$ & Single & 2 & 25.552 & $0,012^{*}$ & 0,020 & 12 \\
& Cumulative & 3 & 22.778 & $0,030^{*}$ & 0,053 & 12 \\
$\mathrm{CPI} \rightarrow \mathrm{O} / \mathrm{N}$ & Single & 2 & 13.744 & 0,317 & 0,329 & 12 \\
& Cumulative & 3 & 20.327 & 0,061 & 0,081 & 12 \\
\hline
\end{tabular}

$\mathrm{O} / \mathrm{N}$ Repo Rate $\rightarrow \mathrm{CPI}$ (There is a causality both in single and cumulative frequency.)

Notes: $\rightarrow$ denotes to causality. Optimal k (frequency) and $\mathrm{p}$ (lag) are determined by Akaike information criterion. Bootstrap $p$-values are based on 1000 replications and $(*)$ denotes $\% 5$ level of statistical significance. Because $n>50$ in this study, we take asymptotic $p$-value in comparison.

Table 3 shows the results of Fourier Granger Causality Test. According to the results, while there seems to be a causality relationship from O/N Repo Rate to the CPI as asymptotic $p$-value is less than 0.05 in that direction, there is no causality relationship from the CPI to the O/N Repo Rate as asymptotic p-value is more than 0.05 as seen from the table above. Therefore, the findings of the analysis indicate 
that the changes in $\mathrm{O} / \mathrm{N}$ Repo Rate do have impacts on Consumer Price Index. On the other hand, as a result of not finding a causality from $\mathrm{CPI}$ to $\mathrm{O} / \mathrm{N}$ Repo Rate, it is understood the inflation rate (CPI) has no significant impact on central bank interest rates (O/N Repo Rate).

\section{Conclusion}

Price stability is both a goal and an intermediate target of monetary policy. In order to achieve price stability, the Central Bank of Republic of Turkey officially implements full-fledged inflation targetting program since 2006. According to that program, the CBRT determines the monetary policy it would implement and the policy instruments it would use in achieving and maintaining price stability. In this context, one of the major instruments used by CBRT is the interest rate corridor between $\mathrm{O} / \mathrm{N}$ borrowing and lending rates in addition to the other instruments including one-week repo rate and reserve requirements.

Turkey, having struggling with high and chronic inflation in 1990's has managed to reduce the inflation rate to the single-digit values thanks to the implicit inflation targeting program executed between 2002-2005 and full-fledged inflation targeting program implemented since 2006. The inflation rate, which stood at \%70 level in 2001, remained under \%10 except for the years of 2008 and 2011 and has not seemed threatening in terms of the economic view. However, inflation rate again at a doubledigit level, around \%15, brought with questions about the accessibility of inflation targets and the credibility of the CBRT. High credit growth, the depreciation of Turkish Lira against currency basket, rising import prices and increases in energy and food prices has great role in the upward trend in inflation especially in recent period.

In this study, Fourier Granger Causality Test has been employed to investigate the relationship between $\mathrm{O} / \mathrm{N}$ repo rates and CPI over the period of 2005-2017. Empirical results indicated evidence in favor of the existence of causality relationship from $\mathrm{O} / \mathrm{N}$ repo rates to $\mathrm{CPI}$ for Turkey. The results obtained from the study are similar to those found in the literature by Crowder and Hoffman (1996), Paleologos and Georgantelis (1999), Lardic and Mignon (2003) and Herwartz and Reimers (2006).

In effective liquidity and credit management, $\mathrm{O} / \mathrm{N}$ repo rates could be increased or decreased or pegged in response to changes in macro-economic and financial environment. Therefore, central banks try to control inflation by making adjustments on interest rates. Given the developments and factors triggering inflation such as credit growth rate and negative shocks to Turkish Lira recently, it seems necessary to increase interest rates gradually. That there is found a causality relationship from $\mathrm{O} / \mathrm{N}$ repo rates to the $\mathrm{CPI}$ meaning that $\mathrm{O} / \mathrm{N}$ repo rates do have impact on inflation rate in this study also supports this idea. Indeed, CBRT has increased $\mathrm{O} / \mathrm{N}$ repo rates in order to response to the significant depreciation of Turkish Lira against currency basket and rising inflation rate recently. Because rising political uncertainty and capital outflows triggers the deterioration in foreign exchange rate and hence might have the potential to cause inflation rate to rise through import inflation channel, it seems inevitable to increase interest rates to combat inflation in the following period.

\section{References}

Argyro, K. (2010). Testing the Fisher Effect in OECD Countries: An Empirical Investigation, Master Thesis, University of Macedonia, Master of Economics, 1-65.

Barcın, B. (2012). The "Unorthodox" Monetary Policy of the Central Bank of the Republic of Turkey: Does it Work?, HEC Paris, Master Thesis, 1-103.

Becker, R., Enders, W. and Lee, J. (2006). A Stationarity Test in the Presence of an Unknown Number of Smooth Breaks, Journal of Time Series Analysis, 3(5), 381-409.

\section{Uluslararası İktisadi ve İdari İncelemeler Dergisi}


Bernanke, Ben S. (2006). The Benefits of Price Stability, Speech, At the Center for Economic Policy Studies and on the Occasion of the Seventy-Fifth Anniversary of the Woodrow Wilson School of Public and International Affairs, Princeton University, Princeton, New Jersey, https://www.federalreserve.gov/newsevents/speech/bernanke20060224a.htm

Berument, H. (1999). The Impact of Inflation Uncertainty on Interest Rates in the UK, Scottish Journal of Political Economy, 4(2), 207-218

Berument, H. and Mohamed, M.J. (2002). The Fisher Hypothesis: a Multi Country Analysis, Applied Economics, (34), 1645-1655.

Booth, G. and C. Ciner (2001), The Relationship between Nominal Interest Rates and Inflation: International Evidence. Journal of Multinational Financial Management, (11), 269-280.

Brazozoza, H and Brzezina, M. (2002), The Relationship between Real Rate Interest Rate and Inflation, NBP Working Papers 23, Narodowy Bank Polski, Economic Research Department, 126.

CBRT(2016).Factsheet,http://www.tcmb.gov.tr/wps/wcm/connect/cccae9f9-4f60-4921-95bd952e100d22ff/CBRT_Factsheet.pdf?MOD=AJPERES\&CVID=

CBRT(2018a). Inflation Report, January 2018, http://www.tcmb.gov.tr/wps/wcm/connect/4c15ad9617dd-4c93-ae8e-17f61275e4a4/inflation2018i_full.pdf

CBRT(2018b).http://www.tcmb.gov.tr/wps/wcm/connect/EN/TCMB+EN/Main+Menu/Core+Function s/Markets/Open+Market+Operations/

Crowder, W. J. and Hoffman, D. L. (1996). The Long-run Relationship between Nominal Interest Rates and Inflation: The Fisher Equation Revisited. Journal of Money Credit and Banking, (28), 102118.

Debelle, G., Masson, P., Savastano, M. and Sharma, S. (1998). Inflation Targeting as a Framework for Monetary Policy, IMF Working Papers, Economic Issues (15), 1-20.

ECB (2009). Price Stability; Why is it Important for you?, ECB Books, 1-80. https://www.ecb.europa.eu/pub/pdf/other/whypricestability_en.pdf

Enders, W. and Jones, P. (2016). Grain Prices, Oil Prices, and Multiple Smooth Breaks in a VAR, Studies in Nonlinear Dynamics \& Econometrics, 20(4), 399-419.

Fama, E. (1975). Short-term Interest Rates as Predictors of Future Inflation. American Economic Review, (65), 269-82.

Fave, P. and Auray, S. (2002), Interest Rate and Inflation in Monetary Models with Ingenious Money Growth Rate, Economic Bulletin, 5(1), 1-10.

Ghazali, Noor A. (2003), A Long Money Test of the Long-run Fisher Effect in the G7 Countries, Applied Financial Economics, (13), 763-769.

Goksu, M. Eşref (2011). Central Bank of Turkey, Interbank Markets Operations, http://xn-80ablwmcepr1b.xn--p1ai/today/ms/fo/seminar_Turkey_06.pdf

Gul, E., and Ekinci, A. (2006). The Causal Relationship between Nominal Interest Rates and Inflation: The Case of Turkey. Scientific Journal of Administrative Development, (4), 54-69.

Guris, S., Guris, B. and Un, T. (2016). Interest Rates, Fisher Effect and Economic Development in Turkey, 1989-2011, Revista Galega de Economía, 2016, (25)2, 95-100. 
Herwartz, H. and Reimers, H.E. (2006). Modelling the Fisher Hypothesis: Worlwide Evidence, Economics Working Papers 2006-04, Christian-Albrechts-University of Kiel, Department of Economics.

Humpage, Owen F. (2008). Rising Relative Prices or Inflation: Why Knowing the Difference Matters, Economic Commentary, Federal Reserve Bank of Cleveland, 1-4.

Iaona, P. (2017). Monetary Policy and Inflation: Is there a Neo- Fisher Effect? Evidence from Inflation Targeting Countries in Central and Eastern Europe, "Ovidius" University Annals, Economic Sciences Series, 17, 578-583.

Incekara, A., Demez, S. and Ustaoglu, M. (2012), Validity of Fisher Effect for Turkish Economy: Cointegration Analysis, Procedia, 58(12), 396-405.

Lardic, S. and Mignon V. (2003). Fractional Co-integration between Nominal Interest Rate and Inflation: An Examination of the Fisher Relationship in G7 countries, Economic Bulletin, 3(14), 1-10.

Million, N. (2003). The Fisher Effect Revisited Through an Efficient Non Linear Unit Root Testing Procedure, Applied Economics Letters, 10 (15), 951-954.

Mishkin, F.S. (1992). Is the Fisher Effect for Real? A Reexamination of the Relationship between Inflation and Interest Rates, Journal of Monetary Economics, 30(2), 195-215.

Mishkin, F.S. and John, S. (1995). An empirical examination of the Fisher effect in Australia. Economic Record, 71(3), 217-229.

Paleologos, J. M. and Spyros E. Georgantelis (1999). Does the Fisher Effect Apply in Greece? A Cointegration Analysis, Economia Internazionale, (52)2, 229 - 243.

Pennacchi, G. (1991). Identifying the Dynamics of Real Interest Rates and Inflation: Evidence Using Survey Data, Review of Financial Studies 4 (1), 53-86.

Poole, W. and Weelock, D. C. (2008). Stable Prices, Stable Economy, Keeping Inflation in Check Must Be No. 1 Goal of Monetary Policymakers, Regional Economists, 1-6.

Ray, S. (2012), Empirical Testing of International Fisher Effect in United States and Selected Asian Economies, Advances in Information Technology and Management, 2(1), 2167-6372.

White, W. (2006). Is Price Stability Enough?, BIS Working Papers, (205), 1-22, https://www.bis.org/publ/work205.pdf

Tsong, C.C., Lee, C.F., Tsai, L.J. and Hu, T.C. (2016). The Fourier Approximation and Testing for the Null of Cointegration, Empirical Economics, 51(3), 1085-1113.

Yilancı, V. (2017). Analyzing the Relationship between Oil Prices and Economic Growth: A Fourier Approach, Econometrics and Statistics, 27 (2), 51-67. 
